\title{
The importance of local processes on river habitat characteristics: A Basque stream case study
}

\author{
Arturo Elosegi*, Lorea Flores and Joserra Díez
}

Faculty of Science and Technology, the University of the Basque Country. PO Box 644, 48080 Bilbao (Spain).

* Corresponding author: arturo.elosegi@ehu.es

Received: 29/1/2010 Accepted: 18/10/2010

\begin{abstract}
The importance of local processes on river habitat characteristics: A Basque stream case study

Habitats are the places where organisms live and are defined by a set of abiotic and biotic characteristics that affect individual fitness and community structure. Therefore, the habitat of river organisms can be linked to a long list of relevant variables, including hydraulics, channel form, substrate composition, water quality, irradiance, and abundance of organic matter. Habitat preferences are well known for some species, particularly salmonids, but large uncertainties remain for many taxa.

River habitats are not composed of static features; instead the features fluctuate as the result of a large set of processes acting from the basin to the local scale. Local processes of importance in shaping river habitats include (depending on river type) channel migration, growth and mortality of riparian trees, formation of wood jams, storage of organic matter, macrophyte development, and travertine deposition. Sometimes it is possible to assess the positive or negative effect of a given process for a particular species, but most often researchers rely on the patterns of physical habitat rather than on the processes that shape these habitats.

As an example of the adjustment of river habitats to local processes, we show data from an experiment in which large wood was reintroduced to a small mountain stream. Wood jams produced large effects on hydraulics and substrate, large increases in the storage of organic matter, increases in invertebrate and fish densities, and changes in ecosystem functioning. This example emphasises the tight relationship between riparian dynamics and in-stream habitat, and the importance of local processes, in this case inputs of large wood to streams. Therefore, the assessment and management of river habitats must take into account not only the habitat itself but also key local processes that are essential for the long-term continuity of this habitat.
\end{abstract}

Key words: Hydraulics, wood, riparian, ecosystem functioning, restoration.

\section{RESUMEN}

\section{La importancia de los procesos locales en las características del hábitat: el caso de un río vasco}

El hábitat, el lugar en el que viven los organismos, viene definido por la serie de características abióticas y bióticas que afectan desde el éxito individual hasta la estructura de la comunidad. Por tanto, el hábitat de los organismos fluviales puede estar determinado por una larga lista de variables importantes, como la hidráulica, la forma del cauce, la composición del sustrato, la calidad del agua, la irradiancia, o la abundancia de materia orgánica. Se conocen bien las preferencias de hábitat de algunas especies, especialmente de salmónidos, pero existe mucha incertidumbre para otros taxones.

Los hábitats fluviales no son entidades estáticas, sino el resultado de una larga serie de procesos que actúan desde la escala de cuenca hasta una escala local. Entre los procesos locales que tienen importancia en el modelado de los hábitat fluviales se incluyen, dependiendo del tipo de río, la migración del cauce, el crecimiento y mortalidad de los bosques de ribera, la formación de acumulaciones de madera, la acumulación de materia orgánica, el desarrollo de macrófitas, o la precipitación de travertinos. A veces se puede evaluar el efecto positivo o negativo de determinado proceso en una especie dada, pero a menudo los investigadores se limitan a evaluar patrones en el hábitat fluvial en lugar de evaluar los procesos que modelan dichos patrones.

Como ejemplo del ajuste del hábitat fluvial a procesos locales, mostramos resultados de un experimento de reintroducción de madera muerta en un arroyo de montaña. Las acumulaciones de madera tuvieron un gran efecto en la hidráulica y en el sustrato, produjeron un fuerte aumento en la acumulación de materia orgánica, aumentos en la densidad de invertebrados y peces, y cambios en el funcionamiento del ecosistema. Este ejemplo recalca la estrecha relación existente entre la dinámica 
de las riberas y el hábitat del cauce, así como la importancia de los procesos locales, en este caso de la caída de troncos a los ríos. Por ello, la evaluación y la gestión de los hábitat fluviales deben tener en cuenta no sólo el hábitat propiamente dicho, sino también procesos locales clave que son esenciales para la continuidad a largo plazo de dicho hábitat.

Palabras clave: Hidráulica, madera, ripario, funcionamiento del ecosistema, restauración.

\section{INTRODUCTION: RIVER HABITAT}

Habitat is one of those loosely defined terms whose widespread use in ecology has elicited strong criticism (Peters, 1991), not all of which is undeserved. It is usually defined as the place where an organism lives or a community is found, and is characterised by its physical or biotic properties (Oxford Dictionary of Ecology). In this sense, it is not easy to measure the quality of a given habitat as a whole because a good habitat for some species can be poor or inhabitable for many others. Even assessing habitat quality for a single species may involve measuring a large number of variables that potentially affect its fitness. The problems, of course, are worse when trying to apply the habitat concept to communities because there is very little agreement regarding the nature of communities amongst ecologists (Ricklefs, 2008).

From a normative point of view, the European Union (EU) Habitat Directive (HD, 92/43/EEC) defined "natural habitat" as terrestrial or aquatic areas distinguished by geographic, abiotic and biotic features, whether entirely natural or seminatural. It then translated this broad definition into two annexes: annex I lists target habitats, defined almost exclusively in phytosociological terms, and annex II lists plant and animal species that must be protected through protection of their habitats. Therefore, it combines two different approaches to habitat: the phytosociological approach, based on community composition, and the species approach, based on specific abiotic and biotic factors that affect the performance of organisms of a given species. Another important piece of legislation in Europe dealing with river habitats is the Water Framework Directive (WFD, 2000/60/EC), which goes beyond water quality and community composition and also in- cludes hydromorphology as an element to be used to assess the status of water bodies.

Given the conceptual divide between the different uses of the term habitat, the assessment and management of river habitats must either a) target some species of priority for some reason (because they are harvested, they are intolerant to human impacts, or are endangered) or b) consider human activities to be the main threat to river habitats in general; thus, the goal is to conserve river reaches that are most natural and to restore others to attain similar environmental characteristics. Given the dynamic characteristics of rivers, restoring environmental characteristics like channel forms might often involve the restoration of channel-shaping processes. For instance, degraded river channels, a common feature in agricultural landscapes, often are disconnected from their former floodplains. In these cases, inputs of large woody debris, either natural or man-made, can enhance the retention of sediments, the recovery of the former channel profile, and reconnection with the floodplain.

Both approaches have merits as well as drawbacks. On the one hand, targeting habitat conservation as a function of the specific needs of priority species has often led to the creation of features that are unnatural for the sole purpose of improving a particular population. For example, fish managers have built low dams, often made of concrete, to create deep pools, which are important refuges for salmonids. On the other hand, restoring habitats without human interference is tricky because we often lack a guiding view, or because reaching this state is simply impossible given societal needs. The desire for this type of restoration can lead to what Dufour \& Piégay (2009) call the myth of a lost paradise. These authors propose focusing on human benefits instead, although it is not clear how to proceed 
when different human interests lead to conflicting goals. The difficulties of restoring habitats with minimal human interference are compounded because, at least in some regions, we still lack a single, agreed-upon classification scheme for river types. Furthermore, although it would be a very useful tool in river restoration, it is not even clear whether such a scheme might be built. It is obvious that very different river types exist and that channel form is linked to catchment characteristics; however, it is often not possible to determine the dividing lines between different river types, and we cannot rule out the existence of multiple alternative stable states for some rivers. Some propose analysing the structure and functioning of river ecosystems from a network perspective (e.g., Benda et al. 2004), but we think their classification of river types is too rough to serve as a guideline for habitat assessment and restoration. All these points make it very risky to assess river quality based on the accordance of channel forms to expectations derived from catchment characteristics.

\section{WHAT CONSTITUTES THE PHYSICAL HABITAT OF RIVER ORGANISMS}

As mentioned above, the habitat of a given species may be defined by multiple important variables, making it very complicated to assess habitat quality unless direct estimates of fitness are made. Furthermore, for most environmental factors, variability, predictability and seasonality are biologically far more meaningful than average values (Gasith \& Resh, 1999), thus making habitat assessment even harder. Even for the bestknown organisms, like salmonids, most habitat modelling is reduced to preference curves related to depth or velocity (Guay et al., 2003), which often may not be enough to correctly assess habitat quality if other variables that affect performance (like food abundance) are neglected. For instance, brown trout prey preferentially on drifting invertebrates, many of which are of terrestrial origin, suggesting that the type and maturity of riparian vegetation can be an important feature of trout habitat (Nakano et al., 1999). Other species are more elusive and rare, and thus, gath- ering even basic distribution data to draw preference curves becomes an almost impossible task. A good example is the Pyrenean desman, an endangered water mole from fast-flowing Iberian streams that is declining at a dangerous rate despite apparent improvements in water quality. Many habitat factors have been blamed for this decline, from hydropower plants to predation by the exotic American mink, but so far we still lack a clear view of the threats to the species (Nores, 2007). Finally, in many cases, the habitat of a given species will include other species, for instance, in the case of freshwater mussels that use fish as vectors for upstream larval dispersal (Williams et al., 1993).

However, because rivers are ecosystems that experience frequent disturbances in the form of droughts and floods and because river food webs depend to a great extent on external inputs of allochthonous organic matter, river organisms seem to have evolved generalist feeding habits and depend to a large extent on abiotic habitat variables (Ward, 1992). This opens up the possibility of describing and assessing physical river habitats based on a limited set of environmental variables. For most fluvial species, the most influential variables seem to be the following: water depth and velocity; temperature and irradiance; size and spatial distribution of particles and sediment permeability; presence, cover and type of macrophytes; large wood; abundance and distribution of channel forms (bars, deep pools, islands, travertine areas); and water quality $(\mathrm{pH}$, conductivity, nutrient status, suspended solids), among others (Allan \& Castillo, 2007). Many species will also depend on a further list of variables, like abundance of algae or fine organic matter, the presence or absence of key predators, and so on (Rodrigo et al., 2007). This situation implies a long list of features to be recorded, and too many to be measured in routine surveys.

\section{LOCAL PROCESSES AND RIVER HABITAT CHARACTERISTICS}

As noted above, multiple factors interact at the local scale to shape river habitats (Fig. 1). 


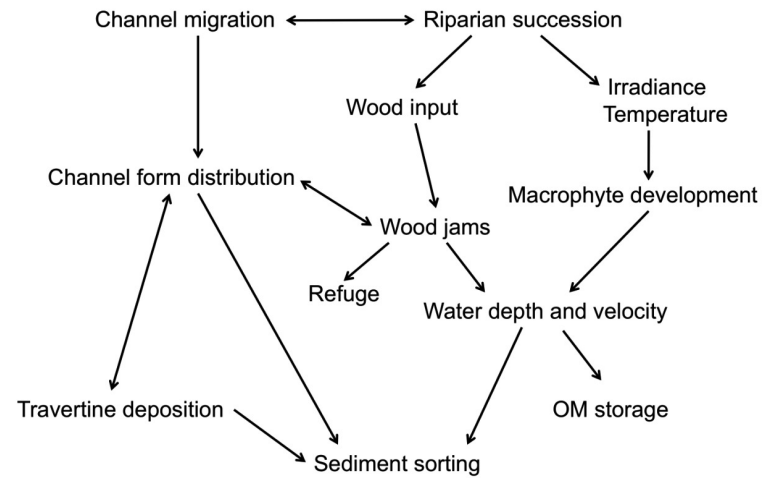

Figure 1. Conceptual model showing some of the main links between local processes and river habitat characteristics. Modelo conceptual que muestra algunas de las principales relaciones entre procesos locales y características del hábitat fluvial.

\section{Water velocity and depth}

The distribution of water velocity and depth is one of the key factors shaping river habitats. Many organisms are adapted to a narrow range of velocity (Franklin et al., 2008), or to a certain type of substrate, which usually is tightly linked to water velocity (Elosegi et al., 2010). The preference curves of some abundant fish species are fairly well known, and on-going research will no doubt yield a wealth of information on many more fish and invertebrate species. However, the role of water velocity goes beyond these preference curves and interacts with other factors, such as spatial distribution of algae, microbial community and macroinvertebrates (Sampaio et al., 2008). Algae tend to grow longer mats in fast flowing waters, both in silted and oligotrophic streams. In the former case, this is because the current prevents siltation; in the later case, it is because the current reduces nutrient limitation (Biggs, 1995). On the other hand, in sand-bottom streams, long algal mats and invertebrates are confined to stable surfaces like logs (Treadwell, 2000; Benke \& Wallace, 2003). These differences in algal distribution will in turn affect the distribution of grazers and even ecosystem processes like nutrient retention (Fisher et al., 2007).

\section{Thermal regime}

Similarly important and also often subject to large local variability is the thermal regime, which has a direct effect on metabolism, growth, and the solubility of gases and other substances (Beschta et al., 1987). Water temperature depends on several factors and mechanisms acting at the local scale (Webb \& Zhang, 1997), primarily direct solar radiation, which is in turn modulated by riparian shading, heat conduction with the substrate, evaporation (which depends on water temperature, air moisture and wind), and upstream water or groundwater inputs (Johnson \& Jones, 2000). Local processes affecting water temperature include removal of riparian shading, either by cutting or by wind storms, and loss of shading can lead to increases of up to $8^{\circ} \mathrm{C}$ (Johnson \& Jones, 2000). Water temperature usually increases downstream, but this pattern is quite variable and depends on local-scale factors like substrate, amount of large wood, and riparian density (Dent et al., 2008). Experimental shading showed that changes in shade affecting short reaches $(150 \mathrm{~m})$ can significantly affect maximum water temperatures and that the effect of shading is more important in bedrock-dominated reaches than in alluvial ones (Johnson, 2004). Other authors found water temperature to be controlled by surface/subsurface water flow even in large rivers (Acuña \& Tockner, 2008), thus showing that changes in flow patterns or in sediment size or permeability could have important effects on river habitats. Small-scale mapping has shown significant spatial variability in water temperature, thus resulting in the availability of thermal refugia (Olsen $\&$ Young, 2009). These differences in temperature can arise from connections between surface and ground water or from the transfer of water between the water column and the hyporheic zone. The microdistribution of organisms often closely tracks these transfer processes; for example, algae grow preferentially in upwelling areas where nutrient concentrations are higher (Fisher et al., 2007). Thermal biology is becoming a hot research topic given future climate scenarios (Mote et al., 2003; IPCC, 2007; Crozier et al., 2008; Mccullough et al., 2009), and shifts in species' distributions have already been documented to occur as a result of increased water temperatures (Hari et al., 2006). 


\section{Sediment size, distribution and type}

Size and sorting of sediments also has great biological significance because many species show strong preference for a given substrate size and because sediment type controls many aspects of stream ecosystem functioning, such as nutrient retention or benthic metabolism. Sediment patches depend on the local flow pattern that is generated at the reach scale but are modified by local flow structures such as boulders or large wood. Quite often, channel forms and sediment structures reflect the past history of the river. For instance, many rivers still show a legacy of longabandoned practices like snagging, which generally results in low loading of dead wood and impoverished channel complexity (Gregory et al., 2003), while in some reaches, the legacy of ancient disturbance can still be seen in the form of large woody debris buried deep in the sediments (Wallace et al., 2001). A process influencing sediment characteristics is travertine deposition, which is common in limestone areas. Travertine streams show very specific habitat features, like abundance of chutes and deep pools, abundant growth of aquatic mosses, and sealed sediments. Travertine deposition affects the density and diversity of invertebrates (Rundio, 2009) and fish (Gorman \& Stone, 1999), the trophic structure of communities (Previsic, 2007), and stream ecosystem functioning (e.g., leaf litter breakdown) (Casas \& Gessner, 1999).

Among sediments, dead organic matter stands out as a key substrate. Accumulations of leaves offer both refugia and food resources to invertebrates, and in small streams, leaf packs form micro-dams that reduce water velocity and retain fine sediments (Webster et al., 2000). Therefore, processes affecting composition and structure of the riparian forest affect in-stream habitats in multiple ways (Cariss \& Dobsson, 1997). Riparian trees shade the channel, limit primary production and, thus, affect the abundance of grazer invertebrates (Nisslow \& Lowe, 2006). Additionally, riparian trees differ greatly in the nutritional quality of their leaves (Abelho, 2001). For instance, Larrañaga et al. (2009) reported that eucalyptus plantations affect invertebrate commu- nities in Basque streams, showing that shredding invertebrates had poor body condition, probably reflecting their poorer quality diet.

Siltation, or deposition of fine sediments, is one of the most prevalent types of freshwater pollution (USEPA, 2002). Siltation is affected by both basin-wide and local-scale processes, especially soil loss from agricultural and forestry practices and is exacerbated by factors that reduce the flushing capacity of the stream, like water abstraction, decreased discharge, or overwidened channels. Siltation has strong effects on community structure and ecosystem functioning (Crowe \& Hay, 2004; Izagirre et al., 2009). For instance, it has been shown to be detrimental to algae, invertebrates and fish habitat (Ryan, 1991; Wood \& Armitage, 1997). It also reduces connectivity between epibenthos and hyporheos (Waters, 1995), which can affect biodiversity (Boulton et al., 1999) and river metabolism (Naegeli \& Uehlinger, 1997).

\section{Macrophytes}

In some lowland streams, macrophytes have a pivotal role in structuring the physical habitat (Warfe et al., 2008). Because of their complex architecture, macrophytes provide a substrate to many algae and invertebrates (Milisa et al., 2006) and a refuge from predators to many fish species (Godinho \& Ferreira, 2006; Padial et al., 2009). Macrophytes affect and are affected by water velocity in their immediate surroundings (Dodds \& Biggs, 2002; Franklin et al., 2008), often trapping sediments and resulting in large changes in bed topography, with detrimental consequences for salmonid spawning (Merz et al., 2008). In temperate regions, macrophyte development is highly seasonal, and thus, physical habitat changes considerably throughout the year. Even in winter, when many macrophytes disappear from rivers, their rhizomes could still play a significant role stabilising sediments.

\section{Large woody debris}

One of the most important local processes affecting habitat in forested streams and rivers is 
treefall and the subsequent movement and formation of wood jams. The role of coarse woody debris in habitat formation has been well described in the literature (Harmon et al., 1986; Gurnell et al., 2001). Dead wood increases habitat diversity, creates new habitats like deep pools and jams, and exerts a large influence on in-channel retention capacity (Larrañaga et al., 2003; Elosegi et al., 2010). The exact role of dead wood depends on the size and disposition of each piece, as logs can form steps, flow deflectors, dams, lateral jams and other features differing in hydraulic and biological significance. Dead wood even affects thermal regime, as the wood might retain large deposits of fine sediments and woody debris that cause the exchange of water between freeflowing and hyporheic zones, thus keeping water cooler (Mutz et al., 2007).

\section{Channel and bank morphology and channel forms}

The relationship between channel features and lateral connectivity with the floodplain is highly dependent on adjacent aquatic habitats (Naiman et al., 2005); however, this has been little studied. Because rivers and their floodplains are pulsed ecosystems where the windows of opportunity are constrained by the habitat template (Uehlinger et al., 2002), any change in lateral connectivity can have profound effects on organism performance. Steep banks form more difficult barriers than smooth ones, and the transition between aquatic and terrestrial habitats is probably easiest in complex channels with dead arms and fallen logs (Gurnell et al., 2005). In fact, lateral arms and other elements of channel complexity generate a soft transition between the channel and the floodplain by acting as preferential paths for organisms between these two habitats. Similarly, log jams and other large wood structures (including beaver dams) increase water stage flooding frequency, and lateral channel migration can result in dead arms, making it easier for organisms to cross the line between terrestrial and aquatic habitats. This ability to cross between habitats could be of great importance, as many species spend part of their lives in both aquatic and terrestrial habitats; during floods, this greater aquatic-terrestrial connectivity might make it easier for aquatic organisms to seek refuge in the floodplains. Therefore, habitat studies should always take into account entire riverfloodplain ecosystems (Tockner et al., 2010).

\section{AN EXAMPLE OF LOCAL PROCESSES AFFECTING RIVER HABITAT CHARACTERISTICS: INPUT OF LARGE WOOD}

As an example of the importance of local processes on formation and conservation of river habitats, here we describe the effects of experimental addition of large wood into Malbazar stream (Guipuscoa, Basque Country, Spain), focusing on short-term changes in hydraulics, associated changes in substrate and organic matter, and the response of biological communities (i.e., macroinvertebrates and fishes). The general hypotheses were that addition of large wood (LW) would result in a) higher retention of sediments, dissolved nutrients and particulate organic matter that would in turn lead to more detritivore macroinvertebrates, more fish, and more efficient use of inputs and b) higher channel complexity, which would lead to enhanced diversity of macroinvertebrate and fish communities. To test these hypotheses, the stream was monitored for two years before and for two years after wood addition. The variables measured included amount and mobility of LW, size and storage of bed sediments, water velocity, nutrients and organic matter, leaf litter decomposition, and invertebrate and fish communities.

\section{Study area and methods}

The study was carried out in Aiako Harria Natural Park, located in Guipuscoa, close to the French border, where 900-m-high mountains close to the Gulf of Biscay result in a temperate, wet climate, with annual rainfall over $2500 \mathrm{~mm}$. As is typical from Basque streams draining to the Atlantic (Elosegi et al., 2006), the streams in the park are characterised by frequent, un- 
predictable floods that affect biological communities and ecosystem functioning. Large inputs of leaf litter into the Añarbe reservoir suggested in-channel retention was largely reduced, probably because of snagging in streams upstream, which was common until recent times. Therefore, it was decided that LW would be introduced into several experimental reaches. Here, we present results from Malbazar, a second-order stream draining a 157 ha catchment covered almost entirely by oak and beech forests. Conductivity is low, $\mathrm{pH}$ is circumneutral, and water quality is excellent. The stream channel is about $4 \mathrm{~m}$ wide, with small chutes and pools, and the streambed is mainly composed of cobbles and boulders. Riparian forests are dense and dominated by mature beech and alder trees.

The highest natural loading of LW in the area, $330 \mathrm{~m}^{3}$ per hectare of streambed, occurred in a first-order tributary and was very close to that predicted by a regression of LW loading on channel width in New Zealand mountain streams covered by southern beech forests (Bailey et al., 2008). Therefore, this regression was used as a rough guideline to set the targeted amount of wood to be restored. A total of $74 \operatorname{logs}$, collected from the forest floor, were added to the reach, totalling $239 \mathrm{~m}^{3} / \mathrm{ha}$. Logs were introduced by hand-held motor winches, forming dams, deflectors and other structures commonly seen in natural streams and were not mechanically fixed in place so that they could move naturally (Fig. 2).

Channel morphology, storage of sediments and organic matter, and macroinvertebrate and fish communities were studied in 2007, before wood addition, and again in 2008 and 2009, after wood addition, which was carried out in January 2008. Channel form, type and storage of sediment were measured in summer from fixed transects with the aid of topographic gear (Díez et al., 2000). A total of 12 transects plus diagonals between all transects were monitored by taking measurements of bed elevation, substrate type and water depth every meter. Storage of coarse particulate benthic organic matter (BOM) in the entire channel (wetted and dry) was studied in late autumn and early summer, which are periods of peak and minimum leaf accumula- tion, respectively, by taking 10 random samples with a $30 \times 30 \mathrm{~cm}$ Surber net $(1 \mathrm{~mm}$ mesh size) and measuring ash free dry mass by gravimetry. Benthic macroinvertebrates were sampled in late autumn and early summer by means of a
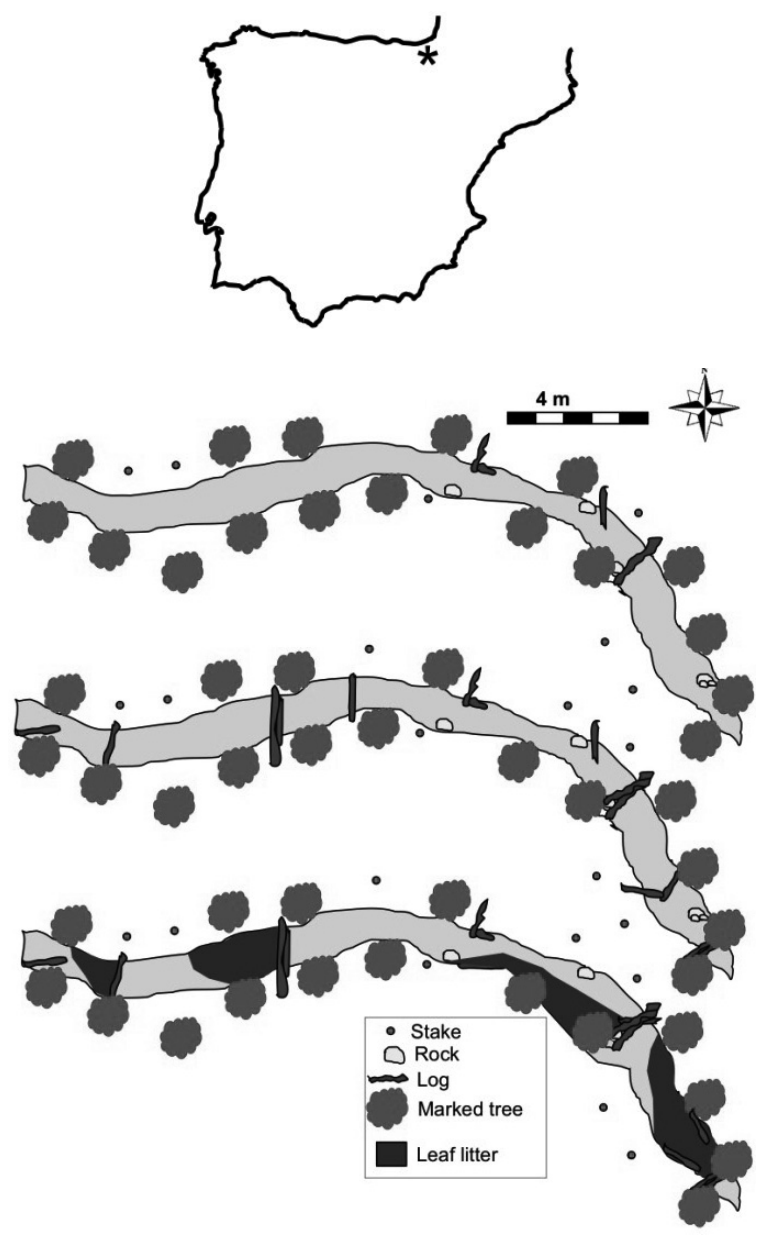

Figure 2. Changes in physical habitat as a result of wood introduction, showing large wood (LW), deposits of leaf litter, large rocks, and stakes and trees used as a reference for cartography in Malbazar stream, Aiako Harria Natural Park (Guipuscoa, Basque Country, Spain). The top panel illustrates the conditions before wood introduction (July 2007), the mid panel shows the site just following wood introduction (February 2008), and the bottom panel shows the site a year and a half later (July 2009). Cambios en el hábitat físico como resultado de la introducción de madera en el arroyo Malbazar, Parque Natural de Aiako Harria (Guipúzcoa, País Vasco, España). Se muestra la madera gruesa (LW), las acumulaciones de hojarasca, los bloques grandes, y estacas y árboles utilizados como referencia para la cartografía. Figura superior, antes de introducir la madera (julio de 2007); figura central, recién introducida la madera (febrero de 2008); figura inferior, año y medio más tarde (julio de 2009). 
$30 \times 30 \mathrm{~cm}$ Surber net $(250 \mu \mathrm{m}$ mesh size), taking 3 random replicates in each of the main substrate types: fine sediments (sand to gravel), coarse sediments (cobbles to boulders), and organic matter. Fish communities were sampled in late autumn by electrofishing the entire reach using the catch removal method, assuming constant capture effort and making as many passes as necessary until a sufficient depletion of captures was obtained. Fish estimates were calculated with Pop/Pro modular statistical software (Kwak, 1992). Fish were anaesthetised with MS222, measured (somatic length to the nearest $\mathrm{mm}$ ), and weighted (to the nearest $\mathrm{g}$ ).

\section{Results and discussion}

The stability of the LW during the study period was remarkable, despite 2008 being rainier than usual. All except one dam remained in place, and only some of the smallest logs in deflectors were scoured, and those only for short distances $(<20 \mathrm{~m}$,
Fig. 2). The stability of the LW agrees with results from the literature (Lienkaemper \& Swanson, 1987; Díez et al., 2001). Wood addition increased the storage of sand, gravel and organic matter, forming deposits upstream from dams up to $1 \mathrm{~m}$ thick (Figs. 2 and 3). Boulders and rocks, on the other hand, decreased in area coverage as a result of channel aggrading. The average depth increased from 5.5 to $11.3 \mathrm{~cm}$, and the maximum depth increased from 44 to $58 \mathrm{~cm}$, especially in large pools associated with the introduced wood jams. Pool formation by introduced logs has often been reported in the literature (Gregory, 1992; Wallace et al., 1995), and deep pools can be very important refuges for large fish.

BOM abundance increased from around 500$600 \mathrm{gAFDM} / \mathrm{m}^{2}$ before wood addition to over $3400 \mathrm{gAFDM} / \mathrm{m}^{2}$ after wood addition (Fig. 4), being primarily found in thick deposits in pools and in frequently flooded lateral terraces (Fig. 2). This case study produced larger effects on BOM storage than others described in the literature (Wa-

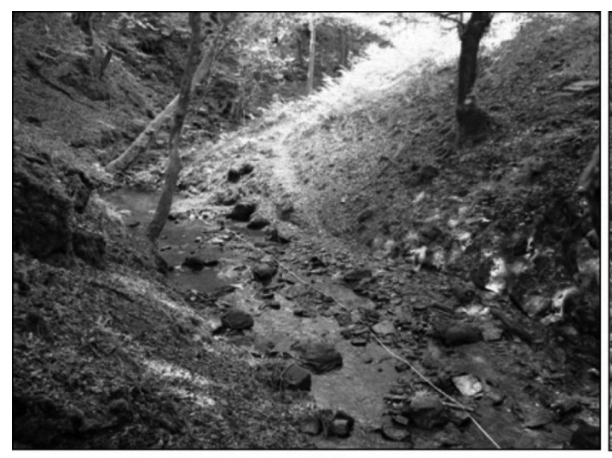

Before

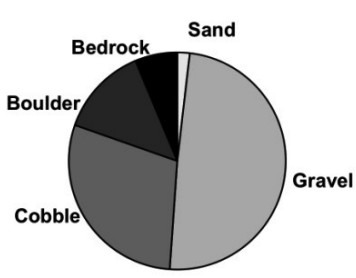

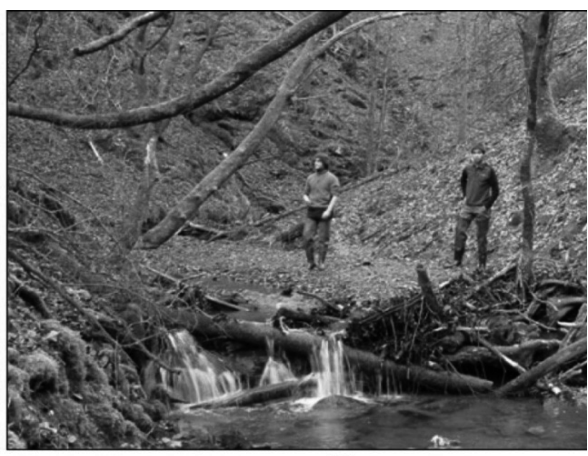

After

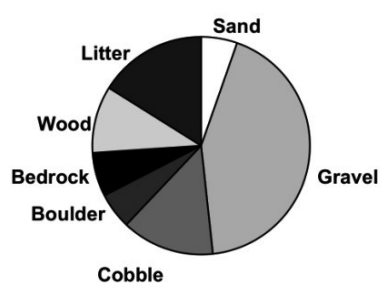

Figure 3. Top panel: Pictures showing rapid habitat changes produced by an artificial wood dam in Malbazar stream, Aiako Harria Natural Park (Guipuscoa, Basque Country, Spain): left, before the dam was built; right, one year after the dam was built. A large gravel bar formed upstream of the dam, and a deep plunge-pool formed downstream. Bottom panel, substrate cover in the stream channel. Panel superior: dos fotografías que muestran cambios del hábitat producidos por una presa artificial de madera en el arroyo Malbazar, Parque Natural de Aiako Harria (Guipúzcoa, País Vasco, España). A la izquierda, antes de construir la presa; a la derecha, un año después de construir la presa: aguas arriba se ha formado una gran barra de grava, y aguas abajo una poza profunda. Panel inferior, cobertura de cada tipo de sustrato en el cauce. 


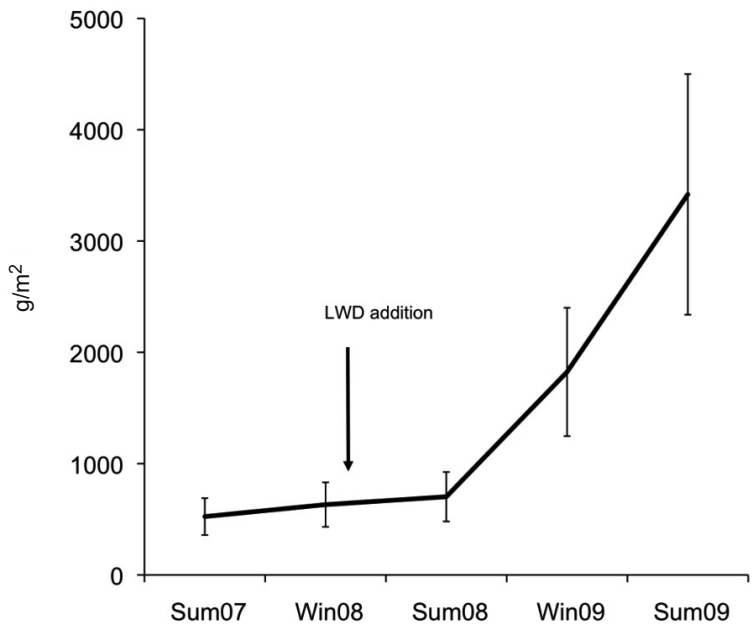

Figure 4. Standing stock of benthic coarse organic particulate matter $\left(\mathrm{gAFDM} / \mathrm{m}^{2}\right)$ of Malbazar stream, Aiako Harria Natural Park (Guipuscoa, Basque Country, Spain). Vertical bars represent standard error. Acumulación $\left(\mathrm{gPSLC} / \mathrm{m}^{2}\right)$ de materia orgánica particulada gruesa bentónica en el lecho del arroyo Malbazar, Parque Natural de Aiako Harria (Guipuzcoa, País Vasco, España). Las barras verticales representan el error estándar.

llace et al., 1995; Entrekin et al., 2008), probably because we created larger dams. Nevertheless, deposits similar in size and characteristics can be found in streams of the area, thus showing that the dams in our experiment were not unnaturally large.

These changes in physical habitat triggered changes in biological communities. For instance, invertebrate densities differed greatly between sediment types (Fig. 5). Sand and gravel had the lowest numbers of total invertebrates and shredders (2133 and 530 individuals $/ \mathrm{m}^{2}$, respectively), followed by cobbles (5013 and 2094 individuals $/ \mathrm{m}^{2}$ ) and were the highest in organic matter $\left(13740\right.$ and 7333 individuals $\left./ \mathrm{m}^{2}\right)$. Because the two substrates that increased most in area were those with the smallest and largest invertebrate densities, the effects on overall reachscale invertebrate numbers were small, but the effects on invertebrate composition were important. More specifically, the reach-scale density of Habroleptoides sp. and Echinogammarus sp. increased, whereas that of Rithrogena sp. and Baetis sp. decreased. Large differences in invertebrate densities between substrate types have been shown previously in Basque streams (Elosegi et al., 2002). On the other hand, of the two fish species occurring in the area, minnow (Phoxinus phoxinus) showed no response, whereas trout biomass (Salmo trutta) increased (Antón et al., 2011). These results confirm the positive effects of large wood on the habitat of large fish, either as a refuge or as a spawning ground (e.g., MacInnis et al., 2008). In the present experiment, the effects seem to be a combination of both factors, as trout seek refuge inside jams and could be seen spawning in the newly formed gravel bars.

In summary, a local factor, namely experimental inputs of large wood into the stream channel, triggered sudden changes in hydraulics, leading to shifts in substrate composition, distri-
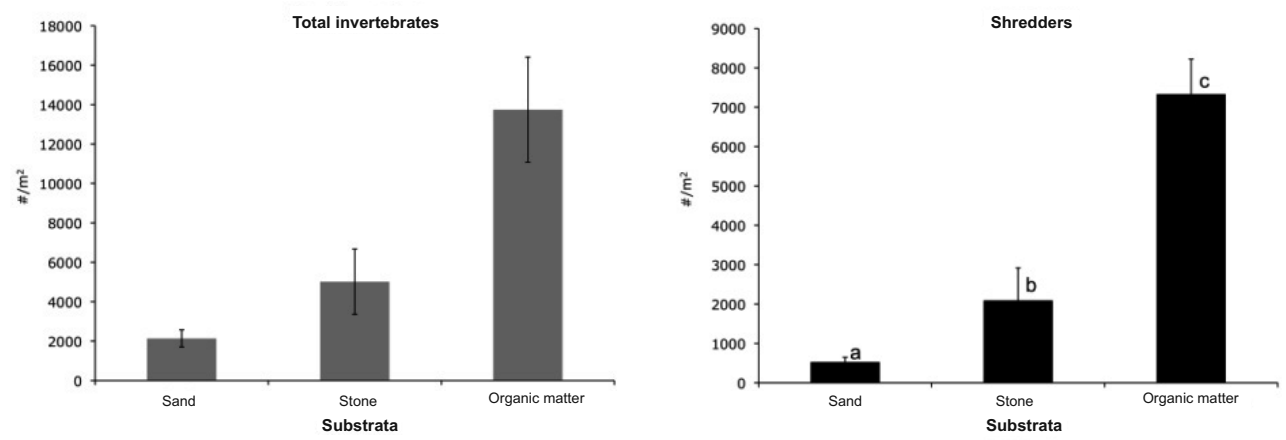

Figure 5. Total benthic (left) and shredder (right) invertebrate density (individuals $/ \mathrm{m}^{2}$ ) in different substrata in the Malbazar stream, Aiako Harria Natural Park (Guipuscoa, Basque Country, Spain). Error bars are standard errors and letters show significant differences $(p<0.05)$ according to the Bonferroni posthoc test after one-way ANOVA on log-transformed data. Densidad (individuos $\left./ \mathrm{m}^{2}\right)$ de invertebrados totales (izquierda) y fragmentadores (derecha) en distintos sustratos en el arroyo Malbazar, Parque Natural de Aiako Harria (Guipúzcoa, País Vasco, España). Las barras de error representan el error estándar y las letras los grupos significativamente diferentes $(\mathrm{p}<0.05)$ según el test post hoc de Bonferroni tras un ANOVA de una vía sobre datos logaritmizados. 
bution and size of riffles and pools, and storage of organic matter, among others. All of these variables are biologically meaningful, and both invertebrate and fish communities responded to the changes in physical habitat.

\section{FINAL REMARKS}

The case study of Malbazar stream is just one example of the importance of local processes in shaping physical habitats and of how readily biologically significant variables can respond. This should lead river managers to better recognise the importance of maintaining local processes to keep rivers healthy and, therefore, to seek strategies to restore some of these processes.

Human activities currently affect the entire planet, and streams and rivers are no exception, most of them being affected by multiple stressors (UNEP, 2007). Moreover, as the human footprint on the planet continues to rise, the pressure on streams and rivers will increase, thus making it more important than ever to assess river status properly to protect healhy rivers and to restore degraded rivers. As we have shown, multiple processes interact to shape habitats at the local scale, creating dynamics and patterns that are not evident to many managers. In our opinion, one of the problems with the conservation of rivers in Europe is that people, even river managers, are so accustomed to rivers that have been simplified and harnessed that they simply fail to perceive the importance of what has been lost. For example, research has shown that students from most countries perceive dead wood to be unnatural in stream channels, unaesthetic and dangerous (Piégay et al., 2005) and fail to recognise its importance as a key habitat element. We have shown experimental evidence of the fast changes in physical habitat and in ecosystem functioning resulting from wood introduction. Other processes mentioned in the present paper can also have profound and rapid effects on river habitats. Therefore, it is important that river scientists and managers take these processes into account when assessing river ecosystems.

\section{ACKNOWLEDGMENTS}

This project was funded by the EU (project LIFE NAT/E/000067) and by the Spanish Ministry of Science and Innovation (project CGL200765176/HID). It also benefited from strong support from the Basque Government (Project IT422-07), the University of the Basque Country (project GIU0538), the Provincial Government of Guipuscoa, the Basque Biodiversity Centre, and the Municipality of Renteria.

\section{REFERENCES}

ABELHO, M. 2001. From litterfall to breakdown in streams: a review. The Scientific World, 1:656-680.

ACUÑA, V. \& K. TOCKNER. 2008. Surface-subsurface water exchange rates along alluvial river reaches control the thermal patterns in an Alpine river network. Freshwater Biology, 54: 306-320.

ALLAN, J. D. \& M. M. CASTILLO. 2007. Stream ecology: structure and function of running waters. Springer, New York. 436 pp.

ANTÓN, A., A. ELOSEGI, L. GARCÍA-ARBERAS, J. R. DÍEZ \& A. RALLO. 2011. Restoration of dead wood in Basque stream channels: effects on brown trout population. Ecology of Freshwater Fish, 20: 461-471.

BAILEY, B. R., L. G. GARRETT \& A. W. EVANSON. 2008. Spatial distribution and influence of woody debris in an old-growth forest river system, New Zealand. Forest Ecology and Management, 256: 20-27.

BENDA, L., N. L. POFF, D. MILLER, T. DUNNE, G. REEVES, M. POLLOCK \& G. PESS. 2004. Network dynamics hypothesis: spatial and temporal organization of physical heterogeneityin rivers. BioScience, 54: 413-427.

BENKE, A. C. \& J. B. WALACE. 2004. Influence of wood on invertebrate communities in streams and rivers. In: The ecology and management of wood in world rivers. S. Gregory \& K. Staley (ed.): 149177. American Fisheries Society, Symposium 37, Bethesda, Maryland.

BESCHTA, R. L., R. E. BILBY, G. W. BROWN, L. B. HOLTBY, \& T. D. HOFSTRA. 1987. Stream temperature and aquatic habitat: fisheries and forestry interactions. In: Streamside management: forestry and fishery interactions. E. O. Salo \& T. W. Cundy 
(ed.): 191-232. Institute of Forest Resources, University of Washington, Seattle, Washington, USA.

BIGGS, B. J. F. 1995. The contribution of disturbance, catchment geology and landuse to the habitat template of periphyton in stream ecosystems. Freshwater Biology, 33: 419-438.

BOULTON, A. J. 1999. An overview of river health assessment: Philosophies, practice, problems and prognosis. Freshwater Biology, 41: 469-479.

CARISS, H. \& M. DOBSON. 1997. Transport and retention of detritus in upland streams: a comparison of an open stream and an adjacent wooded site. Limnetica, 13(2): 85-91.

CASAS, J. J. \& M. O. GESSNER. 1999. Leaf litter breakdown in a Mediterranean stream characterised by travertine precipitation. Freshwater Biology, 41: 781-793.

CROWE, A. \& J. HAY. 2004. Effects on fine sediment on river biota. Cawthron. Report No. 951, 35 pp.

CROZIER, L. G., A. P. HENDRY, P. W. LAWSON, T. P. QUINN, N. J. MANTUA, J. BATTIN, R. G. SHAW \& R. B. HUEY. 2008. Potential responses to climate change in organisms with complex life histories: evolution and plasticity in Pacific salmon. Evolutionary Applications, 1: 252-270.

DENT, L., D. VICK, K. ABRAHAM, S. SCHOENHOLTZ \& S. JOHNSON. 2008. Summer temperature patterns in headwater streams of the Oregon Coast Range. Journal of the American Water Resources Association, 44: 803-813.

DÍEZ, J. R., S. LARRAÑAGA, A. ELOSEGI \& J. POZO. 2000. Effect of removal of woody debris on streambed stability and retention of organic matter. Journal of the North American Benthological Society, 19: 621-632.

DÍEZ, J. R., A. ELOSEGI \& J. POZO. 2001. Woody debris in north Iberian streams: Influence of geomorphology, vegetation and management. Environmental Management, 28: 687-698.

DODDS, W. K. \& B. J. F. BIGGS. 2002. Water velocity attenuation by stream periphyton and macrophytes in relation to growth form and architecture. Journal of the North American Benthological Society, 21: 2-15.

DUFOUR, S. \& H. PIÉGAY. 2009. From the myth of a lost paradise to targeted river restoration: forget natural references and focus on human benefits. River Research and Applications, 25: 568-581.

ELOSEGI, A., A. BASAGUREN \& J. POZO. 2002. Ecology of the Agüera: a review of fourteen years of research in a Basque stream. Munibe, 53: 15-38.
ELOSEGI, A., A. BASAGUREN \& J. POZO. 2006. A functional approach to the ecology of Atlantic Basque streams. Limnetica, 25(1-2): 123-134.

ELOSEGI, A., J. R. DÍEZ \& M. MUTZ. 2010. Effects of hydromorphological integrity on biodiversity and functioning of river ecosystems. Hydrobiologia, 657: 199-215.

ENTREKIN, S. A., J. L. TANK, E. J. ROSI-MARSHALL, T. J. HOELLEIN \& G. A. LAMBERTI. 2008. Responses in organic matter accumulation and processing to an experimental wood addition in three headwater streams. Freshwater Biology, 53: $1642-1657$.

FISHER, S. G., J. B. HEFFERNAN, R. A. SPONSELLER \& J. R. WELTER. 2007. Functional ecomorphology: feedbacks between form and function in fluvial landscape ecosystems. Geomorphology, 89: 84-96.

FRANKLIN, P., M. DUNBAR, \& P. WHITEHEAD. 2008. Flow controls on lowland river macrophytes: A review. Science of the Total Environment, 400: 369-378.

GASITH, A. \& V. RESH. 1999. Streams in Mediterranean climate regions: abiotic influences and biotic responses to predictable seasonal events. $A n$ nual Review of Ecology and Systematics, 30: 5181.

GODINHO, F. N. \& M. T. FERREIRA. 2006. Influence of habitat structure on the fish prey consumption by largemouth bass, Micropterus salmoides, in experimental tanks. Limnetica, 25(3): 657-664.

GORMAN, O. T. \& D. M. STONE. 1999. Ecology of spawning humpback chub, Gila cypha, in the Little Colorado River near Grand Canyon, Arizona. Environmental Biology of Fishes, 55: 115-133.

GREGORY, K. J. 1992. Vegetation and river channel process interactions. In: River conservation and management. P. J. Boon, P. Calow \& G. E. Petts (ed.): 255-269. John Wiley \& Sons, Chichester.

GREGORY, S. V., K. L. BOYER \& A. M. GURNELL. 2003. The ecology and management of wood in world rivers. American Fisheries Society. 444 pp.

GUAY, J. C., D. BOISCLAIR, M. LECLERC \& M. LAPOINTE. 2003. Assessment of the transferability of biological habitat models for Atlantic salmon parr (Salmo salar). Canadian Journal of Fisheries and Aquatic Sciences, 60: 1398-1408.

GURNELL, A. M., G. E. PETTS, D. M. HANNAH, B. P. G. SMITH, P. J. EDWARDS, J. KOLLMANN, J. V. WARD \& K. TOCKNER. 2001. Ri- 
parian vegetation and island formation along the gravel-bed Fiume Tagliamento, Italy. Earth Surface Processes and Landforms, 26: 31-62.

GURNELL, A. M., K. TOCKNER, P. J. EDWARDS \& G. PETTS. 2005. Effects of deposited wood on biocomplexity of river corridors. Frontiers in Ecology and Environment, 3: 377-382.

HARI, R. E., D. M. LIVINGSTONE, R. SIBER, P. BURKHARDT-HOL \& H. GÜTTINGER. 2006. Consequences of climatic change for water temperature and brown trout populations in Alpine rivers and streams. Global Change Biology, 12: 10-26.

HARMON, M. E., J. F. FRANKLIN, F. J. SWANSON, P. SOLLINS, S. V. GREGORY, J. D. LATTIN, N. H. ANDERSON, S. P. CLINE, N. G. AUMEN, J. R. SEDELL, G. W. LIENKAEMPER, K. C. CROMACK \& K. W. CUMMINS. 1986. Ecology of coarse woody debris in temperate ecosystems. Advances in Ecological Research, 15: 133-302.

IPCC. 2007. Climate change 2007: The physical science basis. Summary for policymakers. Contribution of working group I to the fourth assessment report of the Intergovernmental Panel on Climate Change. Paris. 21 pp.

IZAGIRRE, O., A. SERRA, H. GUASCH \& A. ELOSEGI. 2009. Effects of sediment deposition on periphytic biomass, photosynthetic activity and algal community structure. Science of The Total Environment, 407(21): 56944-57000.

JOHNSON, S. L. \& J. A. JONES. 2000. Stream temperature responses to forest harvest and debris flows in western Cascades, Oregon. Canadian Journal of Fisheries and Aquatic Sciences, 57: 30-39.

JOHNSON, S. L. \& J. A. JONES. 2004. Factors influencing stream temperatures in small streams: substrate effects and a shading experiment. Canadian Journal of Fisheries and Aquatic Sciences, 61: 913-923.

KWAK, T. J. 1992. Modular microcomputer software to estimate fish population parameters, production rates and associated variance. Ecology of Freshwater Fish, 1: 73-75.

LARRAÑAGA, S., J. R. DÍEZ, A. ELOSEGI \& J. POZO. 2003. Leaf retention in streams of the Agüera basin (northern Spain). Aquatic Sciences, 65: 158166.

LARRAÑAGA, A., A. BASAGUREN, A. ELOSEGI \& J. POZO. 2009. Impacts of Eucalyptus plantations on Atlantic streams: changes in invertebrate density and shredder traits. Fundamental and Applied Limnology, 175: 151-160.
LIENKAEMPER, G. W. \& F. J. SWANSON. 1987. Dynamics of large woody debris in streams in oldgrowth Douglas-fir forests. Canadian Journal of Forest Research, 17: 150-156.

MACINNIS, C., T. A. FLOYD \& B. R. TAYLOR. 2008. Large woody debris structures and their influence on Atlantic salmon spawning in a stream in Nova Scotia, Canada. North American Journal of Fisheries Management, 28: 781-791.

MCCULLOUGH, D. A., J. M. BARTHOLOW, H. I. JAGER, R. L. BESCHTA, E. F. CHESLAK, M. L. DEAS, J. L. EBERSOLE, J. S. FOOTT, S. L. JOHNSON, K. R. MARINE, M. G. MESA, J. H. PETERSEN, Y. SOUCHON, K. F. TIFFAN \& W. A. WURTSBAUGH. 2009. Research in thermal biology: burning questions for coldwater stream fishes. Reviews in Fisheries Science, 17: 1-26.

MERZ, J. E., J. R. SMITH, M. L. WORKMAN, J. D. SETKA \& B. MULCHAEY. 2008. Aquatic macrophyte encroachment in Chinook salmon spawning beds: lessons learned from gravel enhancement monitoring in the Lower Mokelumne River, California. North American Journal of Fisheries Management, 28: 1568-1577.

MILISA, M., R. M. KEPCIJA, I. RADANOVIC, A. OSTOJIC \& I. HABDIJA. 2006. The impact of aquatic macrophyte (Salix sp and Cladium mariscus (L.) Phol.) removal on habitat conditions and macroinvertebrates of tufa barriers (Plitvice Lakes, Croatia). Hydrobiologia, 573: 283-197.

MOTE, P. W., E. A. PARSOMN, A. F. HAMLET, K. N. IDEKER, W. S. KEETON, D. P. LETTENMAIER, N. J. MANTUA, E. L. MILES, D. W. PETERSON, R. SLAUGHTER \& A. K. SNOVER. 2003. Preparing for climatic change: the water, salmon, and forests of the Pacific Northwest. $\mathrm{Cli}$ matic Change, 61: 45-88.

MUTZ, M., E. KALBUS \& S. MEINECKE. 2007. Effect of instream wood on vertical water flux in low-energy sand bed flume experiments. Water Resources Research, 43: Article number w10424. DOI: 10.1029/2006WR005676

NAEGELI, M. W. \& U. UEHLINGER. 1997. Ecosystem and hyporheic metabolism in a prealpine gravel bed river. Journal of North American Benthological Society, 16: 794-804.

NAIMAN, R. J., H. DECAMPS \& M. E. MCCLAIN. 2005. Riparia. Elsevier/Academic Press, San Diego, USA. 430 pp.

NAKANO, S., Y. KAWAGUCHI, Y. TANIGUCHI, H. MIYASAKA, Y. SHIBATA, H. URABE \& N. 
KUHARA. 1999. Selective foraging on terrestrial invertebrates by rainbow trout in a forested headwater stream in northern Japan. Ecological Research, 14: 351-360.

NISLOW, K. H. \& W. H. LOWE. 2006. Influences of logging history and riparian forest characteristics on macroinvertebrates and brook trout (Salvelinus fontinalis) in headwater streams (New Hampshire, USA). Freshwater Biology, 51: 388-397.

NORES, C. 2007. Galemys pyrenaicus (E. Geoffroy Saint-Hilaire, 1811). In: Atlas y libro rojo de los mamíferos terrestres de España. L. J. Palomo, J. Gisbert \& J. C. Blanco (eds.): 96-98. Dirección General para la Biodiversidad. SECEMSECEMU, Madrid.

OLSEN, D. A. \& R. G. YOUNG. 2009. Significance of river-aquifer interactions for reach-scale thermal patterns and trout growth potential in the Motueka River, New Zealand. Hydrogeology Journal, 17: 175-183.

PADIAL, A. A., S. M. THOMAZ, \& A. A. AGOSTINHO. 2009. Effects of structural heterogeneity provided by the floating macrophyte Eichhornia azurea on the predation efficiency and habitat use of the small Neotropical fish Moenkhausia sanctaefilomenae. Hydrobiologia, 624: 161-170.

PETERS, R. H. 1991. A critique for ecology. Cambridge UP, Cambridge. 336 pp.

PIÉGAY, H., K. J. GREGORY, V. BONDAREV, A. CHIN, N. DAHLSTROM, A. ELOSEGI, S. V. GREGORY, V. JOSHI, M. MUTZ, M. RINALDI, B. WYZGA \& J. ZAWIEJSKA. 2005. Public perception as a barrier to introducing wood in rivers for restoration purposes. Environmental Management, 36: 665-674.

PREVISIC, A., M. KEROVEC \& M. KUCINIC. 2007. Emergence and composition of Trichoptera from karst habitats, Plitvice Lakes region, Croatia. International Review of Hydrobiology, 92: 61-83.

RICKLEFS, R. E. 2008. Disintegration of the ecological community. The American Naturalist, 172: 741-750.

RODRIGO, M. A., C. ROJO, J. LARROSA, M. SEGURA \& M. MOEYS. 2007. Influencia de la concentración de nutrientes y la herviboría sobre la estructura y la función de una comunidad algal. Limnetica, 26(1): 183-198.

RUNDIO, D. E. 2009. Community-habitat relationships in coastal streams in Big Sur, California, USA: travertine influences macroinvertebrate abundance and community structure. Hydrobiologia, 620: 91-108.

RYAN, P. A. 1991. Environmental effects of sediment on New Zealand streams: A review. New Zealand Journal of Marine and Freshwater Research, 25(2): 207-221.

SAMPAIO, A., P. RODRÍGUEZ-GONZÁLEZ, S. VARANDAS, R. M. CORTES \& M. T. FERREIRA.2008. Leaf litter decomposition in western Iberian forested wetlands: lentic versus lotic response. Limnetica, 27(1): 93-106.

TOCKNER, K., M. PUSCH, D. BORCHARDT \& M. S. LORANG. 2010. Multiple stressors in coupled river-floodplain ecosystems. Freshwater Biology, 55: 135-151.

TREADWELL, S. A. 2002. Patterns in community metabolism and biomass of biofilms colonising large woody debris along an Australian lowland river ( $\mathrm{PhD}$ Dissertation). Monash University, Dept. of Biological Sciences. 193 pp.

UEHLINGER U., K. TOCKNER \& F. MALARD. 2002. Ecological windows in glacial stream ecosystems. Eawag News, 54: 20-22.

UNEP. 2007. Global environment outlook 4. Environment for development. United Nations Environment Programme. United Nations, Valletta, Malta. 540 pp.

USEPA. 2002. National water quality inventory (EPA report). U.S. Environmental Protection Agency. 207 pp.

WALLACE, J. B., J. R. WEBSTER \& J. L. MEYER. 1995. Influence of $\log$ additions on physical and biotic characteristics of a mountain stream. Canadian Journal of Fish and Aquatic Sciences, 52: 2120-2137.

WALLACE, J. B., J. R. WEBSTER, S. L. EGGERT, J. L. MEYER \& E. R. SILER. 2001. Large woody debris in a headwater stream: long-term legacies of forest disturbance. International Review of Hydrobiology, 86: 501-513.

WARD, J. V. 1992. Aquatic insect ecology. 1. Biology and habitat. Wiley, New York. 438 pp.

WARFE, D. M., L. A. BARMUTA \& S. WOTHERSPOON. 2008. Quantifying habitat structure: surface convolution and living space for species in complex environments. Oikos, 117: 1764-1773.

WATERS, T. F. 1995. Sediment in streams. Sources, biological effects, and control. American Fisheries Society Monograph. 251 pp. 
WEBB, B. W. \& Y. ZHANG. 1997. Spatial and seasonal variability in the components of the river heat budget. Hydrological Processes, 11: 79-101.

WEBSTER, J. R., J. L TANK, J. B. WALLACE, J.L. MEYER, S. L. EGGERT, T. P. EHRMAN, B. R. WARD, B. L., BENNETT, P. F. WAGNER \& M. E. MCTAMMANY. 2000. Effects of litter exclusion and wood removal on phosphorus and nitrogen retention in a forest stream. Verhandlungen der
Internationale Vereinigung für Theoretische und Angewandte Limnologie, 27: 1337-1340.

WILLIAMS, J. D., M. L. WARREN, K. S. CUMMINGS, J. L. HARRIS \& R. J. NEVES. 1993. Conservation status of fresh-water mussels of the United States and Canada. Fisheries, 18: 6-22.

WOOD, P. J. \& P. D. ARMITAGE. 1997. Biological effects of fine sediment in the lotic environment. Environmental Management, 21(2): 203-217. 